\title{
Role of atelomixis in replacement of phytoplankton assemblages in Dom Helvécio Lake, South-East Brazil
}

\author{
Maria Betânia G. Souza · Cristiane F. A. Barros • \\ Francisco Barbosa · Éva Hajnal · Judit Padisák
}

Received: 19 December 2007/Revised: 7 April 2008/Accepted: 15 April 2008/Published online: 15 May 2008

(C) The Author(s) 2008

\begin{abstract}
Scale and frequency of changes in a lake's physical structure, light dynamics, and availability of nutrients are closely related to phytoplankton ecology. Since phytoplankton assemblages were first described, phytoplankton ecologists concluded that these assemblages provide insight into phytoplankton responses to environmental changes. Objectives of this study were to investigate ecology of phytoplankton during a complete hydrological cycle in the deepest natural lake in Brazil, Dom Helvécio, and to sort species into the list of assemblages, checking its accordance with environmental changes in a tropical system within the middle Rio Doce Lake district, South-East Brazil. Canonical
\end{abstract}

Handling editor: L. Naselli-Flores

M. B. G. Souza $(\bowtie)$. C. F. A. Barros · F. Barbosa Laboratory of Limnology, Institute of Biological Sciences, Federal University of Minas Gerais, Av. Antônio Carlos, 6627, 30161-970 Belo Horizonte, MG, Brazil

e-mail: betania.goncalvessouza@wur.nl

F. Barbosa

e-mail: barbosa@icb.ufmg.br

É. Hajnal · J. Padisák

Department of Limnology, University of Pannonia, Egyetem u. 10, 8200 Veszprem, Hungary

J. Padisák

e-mail: padisak@almos.uni-pannon.hu
Correspondence Analysis, $t$-test, Mann-Whitney $U$-test, and Kruskal-Wallis test were used to analyze climatological, environmental, and plankton data, which were obtained monthly in 2002. A new phytoplankton assemblage, $\mathrm{N}_{\mathrm{A}}$ (atelomixis-dependent desmids), is suggested because atelomixis (robust movement of water occurring once a day) contributed to replacement of species in Dom Helvécio Lake. Stability of stratification, water chemistry, and composition of phytoplankton assemblages characterized two periods. The first period occurred in six rainy months (Jan-Mar and Oct-Dec) when the lake was stratified and phytoplankton was dominated by two assemblages: $\mathrm{N}_{\mathrm{A}}$ and $\mathrm{F}$. The second period occurred in six dry months (Apr-Sep) when the lake was nonstratified and phytoplankton was dominated by four assemblages: S2, X1, A, and $\mathrm{L}_{\mathrm{O}}$. Results suggest that phytoplankton in Dom Helvécio Lake was shaped by seasonal and daily changes of water temperature, even with its lower amplitude of variation within 2002 (El Niño year). These changes promoted water column stratification or mixing, reduced light, and increased nutrient availability. Temperature, therefore, is similarly important to phytoplankton ecology in tropical regions as it is in temperate ones. Sorting phytoplankton species into assemblages matched well with environmental changes and periods identified so it is also suggested that this can be further used as an appropriate tool to manage water quality when evaluating tropical lakes. 
Keywords Phytoplankton assemblages .

$\mathrm{N}_{\mathrm{A}}$ assemblage - Atelomixis · Tropical lake .

Desmids

\section{Introduction}

Evolutionary ecology of phytoplankton is related to major features of aquatic ecosystems (physical structure, light dynamics, availability of nutrients, and interspecific interactions), to frequency, and to scale with which these features alter (Reynolds, 1993). Since phytoplankton assemblages with their physiological, morphological, and ecological attributes were first presented and expanded (Reynolds, 1997a, 2000; Padisák \& Reynolds, 1998; Reynolds et al., 2002; Padisák et al., 2003b), phytoplankton ecologists applied this approach. Assemblages are subject to opportunities provided stochastically and use of these opportunities is influenced by system memory (Reynolds et al., 2000), therefore, there has been an increasing tendency to agree that assemblages provide better insight into phytoplankton responses to environmental changes than individual species or taxonomic groups of traditional analyses (Huszar et al., 1998, 2000; Kruk et al., 2002; Padisák et al., 2006; Naselli-Flores et al., 2007; Salmaso \& Padisák, 2007).

Conservation of Brazilian Atlantic Forest, acknowledged as one of the world's most diverse and threatened biomes, received high scientific and conservational priority (Myers et al., 2000), however, detailed considerations of its aquatic environments are scarce (Barbosa, 1994). Dom Helvécio Lake is the deepest natural lake in Brazil and the biggest one inside the largest remnant of the Brazilian Atlantic Forest in Minas Gerais state (Rio Doce State Park). It is classified as a tropical oligotrophic lake (de Meis \& Tundisi, 1997), although frequent alternations of its trophic status were noted during recent past. Moreover, it is one of the best studied lakes within the middle Rio Doce Lake District (South-East Brazil), being focus of a Long Term Ecological Research project, Brazil-LTER, site \# 4, since 1999 (Barbosa et al., 2004).

Importantly, it has been pointed out by Barbosa \& Padisák (2002), that Dom Helvécio, a warm-monomictic lake, presents a particular stratification pattern, atelomixis, a diurnal mixing restricted to the epilimnion. More explicitly, and according to Gunkel \& Casallas (2002), the term atelomixis is used for lakes in which partial mixing processes, during stratification periods, lead to complex stratification and multiple thermoclines. This complex stratification pattern is a driving force upon phytoplankton community structure and the determinant role of atelomixis has been explored in some other tropical and subtropical systems in Brazil (Bouvy et al., 2003; Lopes et al., 2005; Becker et al., 2008).

Basic phytoplankton composition of Dom Helvécio Lake has been described (Forte-Pontes, 1980; Reynolds, 1997b; Barbosa \& Padisák, 2002; Padisák et al., 2003a; Borics et al., 2005), and pronounced seasonal changes on this tropical system, as presented by Melack (1979), have also been shown, with desmids and filamentous cyanobacteria being most dominant in different seasons (Barros et al., 2006). However, so far, no one has applied phytoplankton assemblages approach to any limnological data from any ecosystem in the middle Rio Doce Lake District. For instance, following mentioned seasonality in Dom Helvécio, it is reasonable to expect based on Reynolds et al. (2002), that $\mathrm{N}$ assemblage (one group with desmids) and S2 assemblage (one group with cyanobacteria) can be most dominant in different seasons in this lake. It is of our view that further use of this system might offer a more comprehensive account of why these groups present this dynamics in Dom Helvécio Lake, than what has been done up to now.

Objectives were to investigate ecology of phytoplankton during a complete hydrological cycle of Dom Helvécio Lake in order to evaluate its plankton dynamics, to detect temporal trends, and to sort species into the list of assemblages proposed by Reynolds et al. (2002), checking its accordance with environmental changes in a tropical ecosystem within the middle Rio Doce Lake District.

\section{Materials and methods}

Dom Helvécio Lake has dendritic shape, is surrounded by dense secondary forest and is the largest lake $\left(6.87 \mathrm{~km}^{2}\right)$ and the deepest one (maximum depth of $32.5 \mathrm{~m}$; mean depth of $12.1 \mathrm{~m}$ ) located at an altitude of $300 \mathrm{~m}$ a.s.1., in the middle Rio Doce Lake District, formed by a landslide about 12,000 years ago (de Meis 
\& Tundisi, 1997; Henry et al., 1997). One third of the lakes of this District is located inside the State Park of Rio Doce (36,113 ha), Minas Gerais, Brazil $\left(19^{\circ} 29^{\prime} 24^{\prime \prime}-19^{\circ} 48^{\prime} 18^{\prime \prime} \mathrm{S}\right.$; $\left.42^{\circ} 28^{\prime} 18^{\prime \prime}-42^{\circ} 38^{\prime} 30^{\prime \prime} \mathrm{W}\right)$. Hydrological budget of Dom Helvécio Lake is dominated by precipitation, evaporation, and groundwater exchange (de Meis \& Tundisi, 1997). It is stratified between September and April and basically isothermal from May to August (Henry \& Barbosa, 1989; Barbosa, 1997). Local climate is tropical semi-humid with average temperatures around $25^{\circ} \mathrm{C}$ and with 4-5 months of dryness (Tundisi, 1997) when temperatures around $18^{\circ} \mathrm{C}$ characterize the coldest months.

One open-water station for sampling was defined at the deepest spot of Dom Helvécio Lake. Samples were collected monthly with a van Dorn bottle at subsurface (100\% of incident light), Secchi depth (15\% of incident light) and three times Secchi depth (1\% of incident light), during 2002. Percentage of incident light was estimated according to measurements with Secchi disk (Cole, 1983) and verified with a radiometer. Vertical profiles of water temperature, $\mathrm{pH}$, and electric conductivity were measured with a Horiba multi probe sensor. Stability of stratification of each month (Cole, 1983) was calculated using density tables from Hutchinson (1957). Mixing zones $\left(\mathrm{z}_{\mathrm{mix}}\right)$ were identified from temperature profiles. Ratio of euphotic zone $\left(\mathrm{z}_{\mathrm{eu}}\right)$ to mixing zone $\left(\mathrm{z}_{\mathrm{mix}}\right)$ was used as an index of light availability in the mixing zone (Jensen et al., 1994). Daily measurements (10 days before each sampling) of air temperature (mean, maximum, and minimum), precipitation, and wind velocity were provided by a meteorological station about $50 \mathrm{~km}$ distant from the State Park.

Total phosphorus (TP), soluble reactive phosphorus (SRP: $\mathrm{P}_{-} \mathrm{PO}_{4}^{-3}$ ), total nitrogen $(\mathrm{TN})$, dissolved inorganic nitrogen (DIN: $\mathrm{N}_{-} \mathrm{NO}_{3}^{-}, \mathrm{N}_{-} \mathrm{NO}_{2}^{-} \mathrm{N}-\mathrm{NH}_{4}^{+}$), and soluble reactive silicate ( $\mathrm{SRSi}$ ) were measured according to Golterman et al. (1978), Koroleff (1976) and Mackereth et al. (1978).

Phytoplankton samples were preserved with Lugol's iodine solution and at least 400 specimens (settling units) of the most frequent species were enumerated (species-specific counting error for these species $\leq 10 \%$; Lund et al., 1958) using an inverted microscope (Utermöhl, 1958). Algal biovolumes were approximated by geometric shapes of cells (Edler, 1979) using ALGAMICA software (Gosselain \& Hamilton, 2000). Biovolume data were transferred to biomass (fresh weight) supposing a specific gravity of $1 \mathrm{mg} \mathrm{mm}^{-3}$ and cell size was calculated as total biovolume/total density. Minimum of 5\% contribution to total biomass was required for considering a species as dominant (Padisák et al., 2003b). Taking into account oligotrophy of Dom Helvécio Lake, 2001 of water from each sampled depth were pumped in low speed $\left(0.5 \mathrm{l} \mathrm{s}^{-1}\right)$ and concentrated with a net $(68 \mu \mathrm{m})$ for zooplankton analysis. Organisms were colored with Bengal rose, fixed with $4 \%$ formaline, and then counted in Sedgewick-Rafter chambers (Bottrell et al., 1976).

Periods of phytoplankton succession were identified according to variations of phytoplankton biomass, composition, and average cell volume. Differences among months and periods, related to size of organisms and desmid forms, were assessed by nonparametric Kruskal-Wallis test using data from samples at $100 \%, 15 \%$ and $1 \%$ of incident light as replicates of each month. Differences between periods related to climatologic variables of Rio Doce State Park Region (values from 10 days before each sampling), and of abiotic and biotic environment variables (values from samples at 100\%, 15\% and 1\% of incident light) were assessed by parametric $t$-test (two-sided, independent samples) or nonparametric Mann-Whitney $U$-test (two-sided), depending on normal distribution of data and equality of variances. Differences among rainy trimesters and six dry months, related to wind velocity and stability of stratification, were assessed by ANOVA or nonparametric Kruskal-Wallis test, depending on normal distribution of data and equality of variances. Canonical Correspondence Analysis (CCA) was performed using Canonical Ordination software (CANOCO version 4; Ter Braak \& Šmilauer, 1998) to ordinate phytoplankton data from different periods with environmental and biological variables. These variables were selected after Monte Carlo permutations in order to run the analysis. Statistical significance of the first axis was evaluated and for the second axis same test was applied with main vectors correlated with the first axis as co-variables.

\section{Results}

During rainy months, January to March and October to December, mean, maximum, and minimum 
temperatures of air, temperature of water, and precipitation increased (Tables 1,2 ). Wind velocity (Table 1) presented higher values during dry months (Apr-Sep), and during the second rainy trimester than in the first one (Kruskal-Wallis $H_{(2,120)}=19.15$; $P<0.001)$, thus presenting no difference between periods (Table 2). Seasonality of temperature, backed up by decrease of wind velocity, resulted in lower stability of stratification during dry months (Table 2), and although higher values were calculated for the first rainy trimester (Fig. 1), there was no substantial difference between rainy trimesters $\left(F_{(2,12)}=3.8\right.$; $P<0.10)$. Seasonality was clear for stability of stratification, whereas depths of euphotic zone did not show large changes (Fig. 1). Mixing zone depths followed thermal stability and began to extend in April reaching deepest values (mixing down to the bottom of the lake) in August and September. Ratio of $\mathrm{z}_{\mathrm{eu}} / \mathrm{z}_{\mathrm{mix}}$ showed higher values, indicating better light conditions, in the stratified summer than in the isothermal winter (Tables 1, 2).

During dry months, electric conductivity and TP concentration increased. Ratio of TN:TP, SRP, and $\mathrm{pH}$ also varied seasonally with higher values during stratification than during mixing but no major changes between periods were recorded for $\mathrm{TN}$ and DIN concentrations, including for soluble forms $\mathrm{N}-\mathrm{NO}_{2}^{-}$and $\mathrm{N}-\mathrm{NH}_{4}^{+}$. During dry months, SRSi and $\mathrm{N}^{-\mathrm{NO}_{3}^{-}}$were higher than in rainy ones (Tables 1,2 ).

Peaks of total densities of zooplankton and phytoplankton were observed in May (Fig. 2a, b). Total density of zooplankton was higher in dry months, whereas total density of phytoplankton did not show variation between periods (Table 2). Seasonal pattern of phytoplankton biomass was close to unimodal (Fig. 2c) with annual average of $6 \mathrm{mg} \mathrm{l}^{-1}$, with higher values during dry months (Table 2), when maxima occurred in May $\left(11 \mathrm{mg} \mathrm{l}^{-1}\right)$, June (29 $\left.\mathrm{mg} \mathrm{l}^{-1}\right)$, and August $\left(15 \mathrm{mg} \mathrm{l}^{-1}\right)$.

Copepoda and Rotifera were the most abundant groups of zooplankton and their clear replacement was observed. Copepods prevailed between Apr-Sep while rotifers dominated from Jan-Mar and Oct-Dec (Fig. 3a, Table 2). Dominant groups of phytoplankton were Zygmemaphyceae, Cyanobacteria, and Chlorophyceae. Similar two periods were identified according to changes in phytoplankton biovolume (Fig. 3b) and species composition. High contribution of desmids was observed during rainy/stratified months (Jan-Mar and
Oct-Dec), corresponding to the first period. High contribution of Cyanobacteria, diatoms, chlorophyceans, and dinoflagellates was observed in dry/mixing months (Apr-Sep), corresponding to the second period. Phytoplankton cells (Fig. 4) were bigger in the second period than in the first one (Kruskal-Wallis $\left.H_{(11,36)}=26.63 ; P<0.01\right)$.

A total of 95 taxa were counted and 65 contributed to more than $98 \%$ of total density, however, only 14 contributed to $70-98 \%$ of total biomass and 11 represented dominant assemblages of each month. Phytoplankton assemblages' replacement throughout the year was evident (Table 3). First period was characterized by dominance of assemblage F (Botryococcus braunii Kützing) and desmid assemblages mainly represented by Staurastrum smithii (G. M. Smith) Teiling, during Jan-Mar, and by Cosmarium contractum Kirchner and Staurodesmus incus (Brébisson) Teiling, during Oct-Dec. Second period was characterized by dominance of assemblages S2 (Lyngbya sp. and Planktolyngbya sp.), X1 (Chlorella sp.), A (Urosolenia longiseta Zacharias), and $\mathrm{L}_{\mathrm{O}}$ (Peridinium inconspicuum Lemmermann), during Apr-Sep. Throughout the year, Cosmarium asphaerosporum Nordstedt and Closterium moniliferum (Bory) Ehrenberg, two desmids, and Gymnodinium sp., one dinoflagellate, were recognized as subdominants (not present in Table 3).

Desmid species were separated according to their morphological complexity to analyze temporal replacement within the most species-rich group. Forms without "arms" or with short ones were considered "simple forms" (e.g., Cosmarium) and those with long projections or processes were considered as "complex forms" (e.g., some Staurastrum). Divergence between relative abundance of simple and complex forms of desmids was observed within the first period, before and after mixing of the lake (Fig. 5). Complex forms (Kruskal-Wallis $H_{(2,36)}=20.53 ; P<0.001$ ) were more abundant during Jan-Mar, while simple forms (Kruskal-Wallis $H_{(2,36)}=11.10 ; P<0.01$ ) were more abundant during Oct-Dec.

CCA model (Fig. 6) added eight abiotic variables and density of copepods and rotifers as vectors. First two axes explained $82 \%$ of variance of biological data (Table 4). Monte Carlo permutation test with vectors water temperature, TP, SRP, TN:TP ratio, and N-NO ${ }_{3}^{-}$ showed statistical significance $(P<0.05)$. Other variables such as $\mathrm{pH}$, conductivity, SRSi and density of copepods and rotifers also contributed to species- 


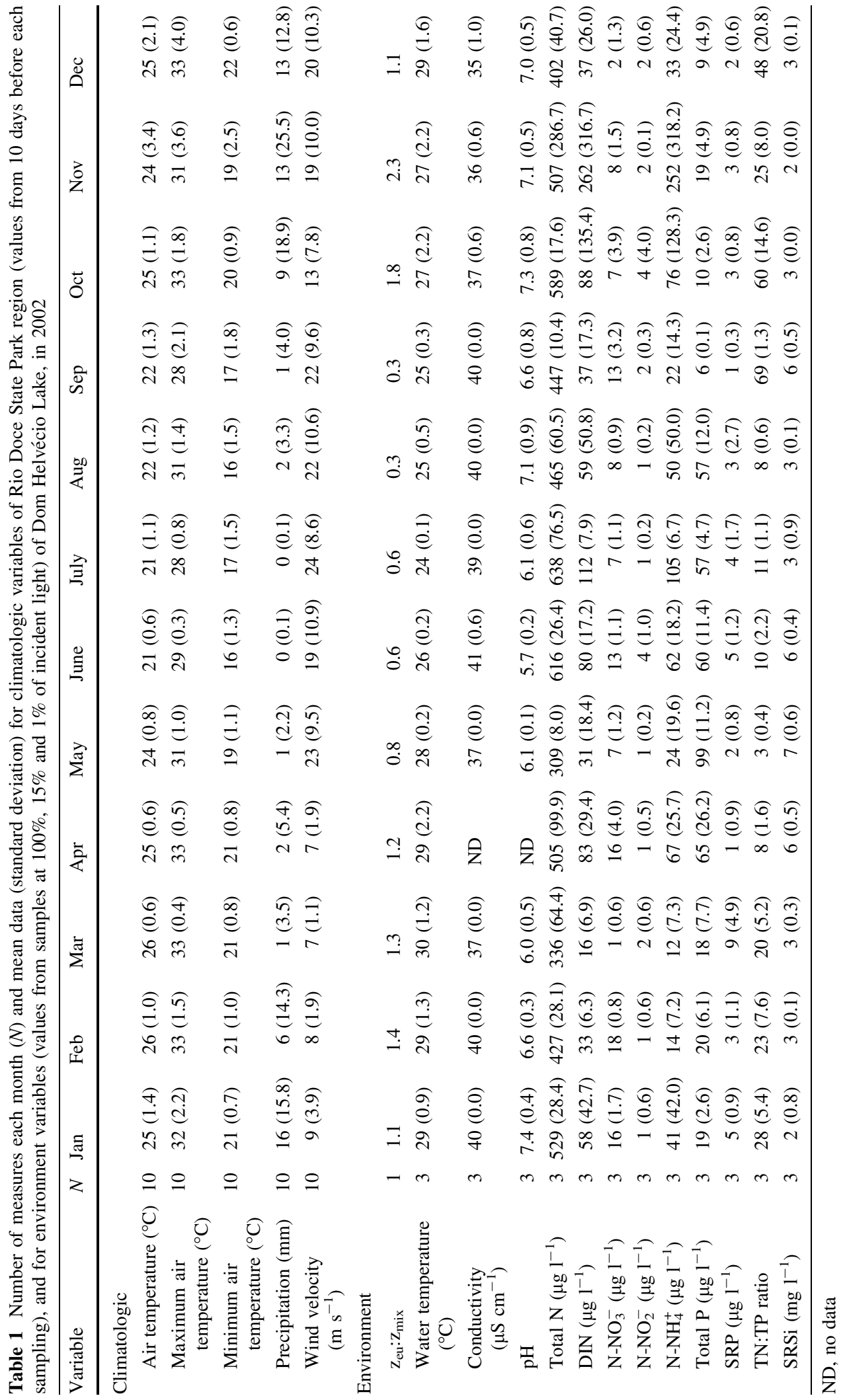


Table 2 Results of statistical tests $(P<0.05$ in bold $)$ to establish differences between two periods in 2002, and number of measures in six rainy months $\left(N_{1}\right)$ and in six dry months $\left(N_{2}\right)$ of climatologic variables of Rio Doce State Park Region

\begin{tabular}{|c|c|c|c|c|}
\hline Variable & $N_{1}$ & $\mathrm{~N}_{2}$ & Statistics & $P$ \\
\hline \multicolumn{5}{|l|}{ Climatologic } \\
\hline Air temperature $\left({ }^{\circ} \mathrm{C}\right)$ & 60 & 60 & $t$-test $; t=6.9$ & $<\mathbf{0 . 0 0 1}$ \\
\hline Maximum air temperature $\left({ }^{\circ} \mathrm{C}\right)$ & 60 & 60 & $U$-test; $U=785.5, Z=5.3$ & $<\mathbf{0 . 0 0 1}$ \\
\hline Minimum air temperature $\left({ }^{\circ} \mathrm{C}\right)$ & 60 & 60 & $U$-test; $U=419.0, Z=7.2$ & $<\mathbf{0 . 0 0 1}$ \\
\hline Precipitation $(\mathrm{mm})$ & 58 & 60 & $U$-test; $U=1177.0, Z=3.0$ & $<\mathbf{0 . 0 1}$ \\
\hline Wind velocity $\left(\mathrm{m} \mathrm{s}^{-1}\right)$ & 60 & 60 & $U$-test; $U=1459.5, Z=-1.8$ & $<0.10$ \\
\hline \multicolumn{5}{|l|}{ Environment (abiotic) } \\
\hline $\mathrm{z}_{\mathrm{eu}}: \mathrm{z}_{\mathrm{mix}}$ & 6 & 6 & $U$-test; $U=2.0, Z=2.6$ & $<\mathbf{0 . 0 5}$ \\
\hline Stability of stratification $\left(\mathrm{g} \mathrm{cm} \mathrm{cm}^{-2}\right)$ & 6 & 6 & $t$-test $t=2.7$ & $<\mathbf{0 . 0 5}$ \\
\hline Water temperature $\left({ }^{\circ} \mathrm{C}\right)$ & 18 & 18 & $U$-test; $U=63.0, Z=3.1$ & $<\mathbf{0 . 0 1}$ \\
\hline Conductivity $\left(\mu \mathrm{S} \mathrm{cm}^{-1}\right)$ & 18 & 15 & $U$-test; $U=61.5, Z=-2.7$ & $<\mathbf{0 . 0 1}$ \\
\hline $\mathrm{pH}$ & 18 & 15 & $U$-test; $U=71.5, Z=2.3$ & $<\mathbf{0 . 0 5}$ \\
\hline Total $\mathrm{N}\left(\mu \mathrm{g}^{-1}\right)$ & 18 & 18 & $U$-test; $U=124.0, Z=-1.2$ & $<0.25$ \\
\hline $\operatorname{DIN}\left(\mu \mathrm{g} \mathrm{l}^{-1}\right)$ & 18 & 18 & $U$-test; $U=115.5, Z=-1.5$ & $<0.15$ \\
\hline $\mathrm{N}-\mathrm{NO}_{3}^{-}\left(\mu \mathrm{g} \mathrm{l}^{-1}\right)$ & 18 & 18 & $t$-test; $t=-2.1$ & $<\mathbf{0 . 0 5}$ \\
\hline $\mathrm{N}-\mathrm{NO}_{2}^{-}\left(\mu \mathrm{g} \mathrm{l}^{-1}\right)$ & 18 & 18 & $U$-test; $U=106.5, Z=1.8$ & $<0.10$ \\
\hline $\mathrm{N}-\mathrm{NH}_{4}^{+}\left(\mu \mathrm{g}^{-1}\right)$ & 18 & 18 & $U$-test; $U=109.0, Z=-1.7$ & $<0.10$ \\
\hline Total $\mathrm{P}\left(\mu \mathrm{g} \mathrm{1^{-1 } )}\right.$ & 18 & 18 & $U$-test; $U=53.0, Z=-3.4$ & $<\mathbf{0 . 0 0 1}$ \\
\hline $\mathrm{SRP}\left(\mu \mathrm{g} \mathrm{1^{-1 } )}\right.$ & 18 & 18 & $t$-test $t=2.4$ & $<\mathbf{0 . 0 5}$ \\
\hline $\mathrm{TN}: \mathrm{TP}$ ratio & 18 & 18 & $U$-test; $U=49.0, Z=3.6$ & $<\mathbf{0 . 0 0 1}$ \\
\hline SRSi $\left(\mathrm{mg} \mathrm{l}^{-1}\right)$ & 18 & 18 & $U$-test; $U=21.5, Z=-4.4$ & $<\mathbf{0 . 0 0 1}$ \\
\hline \multicolumn{5}{|l|}{ Environment (biotic) } \\
\hline Total density of zooplankton (ind $\mathrm{m}^{-3}$ ) & 18 & 17 & $t$-test; $t=-4.4$ & $<\mathbf{0 . 0 0 1}$ \\
\hline Density of Copepoda (ind $\mathrm{m}^{-3}$ ) & 18 & 17 & $U$-test; $U=16.0, Z=-4.5$ & $<\mathbf{0 . 0 0 1}$ \\
\hline Density of Rotifera (ind $\mathrm{m}^{-3}$ ) & 18 & 17 & $U$-test; $U=8.0, Z=4.8$ & $<\mathbf{0 . 0 0 1}$ \\
\hline Total density of phytoplankton (ind $\mathrm{ml}^{-1}$ ) & 18 & 18 & $U$-test; $U=157.0, Z=0.2$ & $<0.90$ \\
\hline Total biomass of phytoplankton $\left(\mathrm{mg} \mathrm{l}^{-1}\right)$ & 18 & 18 & $t$-test; $t=-2.1$ & $<\mathbf{0 . 0 5}$ \\
\hline
\end{tabular}

environment relationship (Table 5) and, therefore, were also added. Stratified and mixing periods were clearly separated, as well as their dominant phytoplankton assemblages, by both axes. Speciesenvironment correlation for axes 1 and 2 were high (Table 4) indicating agreement between the two matrixes and corroborating results outlined above.

\section{Discussion}

Physical structure of Dom Helvécio Lake is characterized by two major events, and both are driven by climatic regime. One of these events operates at seasonal scale dividing the year into a stratified (values from 10 days before each sampling), and of environment variables (values from samples at $100 \%, 15 \%$ and $1 \%$ of incident light) of Dom Helvécio Lake, South-East Brazil 


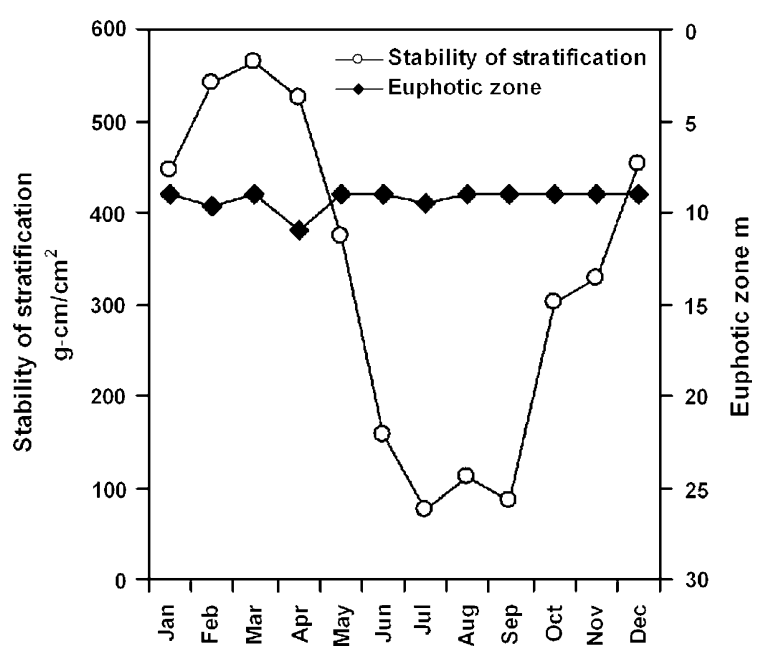

Fig. 1 Monthly changes of euphotic zone depth (m) and stability of stratification $\left(\mathrm{g} \mathrm{cm} \mathrm{cm}^{-2}\right)$ of Dom Helvécio Lake, South-East Brazil, in 2002

Padisák (2002). Most essential environmental variables $(\mathrm{P}, \mathrm{N})$ and descriptors of phytoplankton development (species composition, dominant assemblages, and average cell volume) clearly followed the seasonal pattern except for the peak of phytoplankton biomass at the beginning of full mixing, which was probably due to resuspension of cells that sank to the hypolimnion during preceding stratification period and partly to new growth as consequence of increased nutrient availability. This peak of plankton biomass and annual average, however, remained low when compared to other tropical lakes (e.g., Huszar et al., 1998, 2000) as well as to temperate ones (e.g., Huszar \& Caraco, 1998; Naselli-Flores \& Barone, 1998).

Meteorological conditions are considered to govern phytoplankton dynamics in temperate regions (Reynolds, 1984). Tropical lakes are traditionally considered as ecosystems exposed to low climatic variability, therefore, as ecosystems supporting uniform assemblages which may persist for years (Melack, 1979). Results suggest that seasonal changes in water temperature and density, driven by climate, are similarly important in tropical regions as in temperate ones. These changes define mixing periods together with input of light and energy that control balance between phytoplankton growth and loss. Even with lower amplitude of variation within 2002 (El Niño year), temperature seems to be the major factor determining: (i) occurrence and maintenance of water column stratification (Oct-Mar) with high stability of stratification, partial atelomixis, and relatively transparent water; and (ii) occurrence of water column mixing (Apr-Sep), when light availability is reduced $\left(\mathrm{z}_{\mathrm{eu}}: \mathrm{z}_{\mathrm{mix}}\right.$ ratio decrease) and nutrient availability is increased.

Roles and relevance of wind velocity and fetch in descending thermocline and in successional and vertical dynamics of phytoplankton have been explored on tropical ecosystems (Fabbro \& Duivenvoorden, 1996; Bouvy et al., 2006); however, no direct studies of wind action relating to temporal and spatial distribution of phytoplankton have been done in Dom Helvécio Lake, yet. In our study, higher values of wind velocity coincided with periods of lower stability of stratification (Apr-Sep), and may have helped full mixing of the lake, but this is insufficient to establish a causal relationship. Dom Helvécio Lake is considered to be well protected from wind action because a dense secondary forest surrounds the lake and its dendritic shape shelters it from wind blowing from some directions (Henry \& Barbosa, 1989). Moreover, in the South-Eastern region of Brazil, circulation systems of polar anticyclone and subtropical anticyclone (southern Atlantic) have a dynamic equilibrium (Nimer, 1989). This climate, according to Tundisi (1997), influences vertical circulation of Dom Helvécio Lake seasonally, and is directly related to lower air temperatures of winter (dry) periods: a slow process of mixing starts in May, corrodes the thermocline, and cold masses during winter are accountable for surface cooling that produces isothermal conditions in July, as shown in Barros et al. (2006). In fact, there was no difference of wind velocity in Rio Doce Park region between rainy and dry periods in 2002, therefore, it was concluded that primary driving force in seasonal physical structure of water column of Dom Helvécio Lake in 2002 was unlikely resulting from changes in wind velocities within the region, as also seen in Hambright et al. (1994).

Desmids are usually dominant in plankton composition of Dom Helvécio Lake and because of their role it was pertinent to analyze their assemblages in detail. Establishment and dominance of desmids is dependent on the particular mixing pattern of Dom Helvécio Lake, atelomixis (Barbosa \& Padisák, 2002), and a new assemblage type, $\mathrm{N}_{\mathrm{A}}$, is suggested according to this relation. Assemblage $\mathrm{N}_{\mathrm{A}}$ principally comprises small, \pm iso-diametrical desmids (Cosmarium, Staurastrum, 

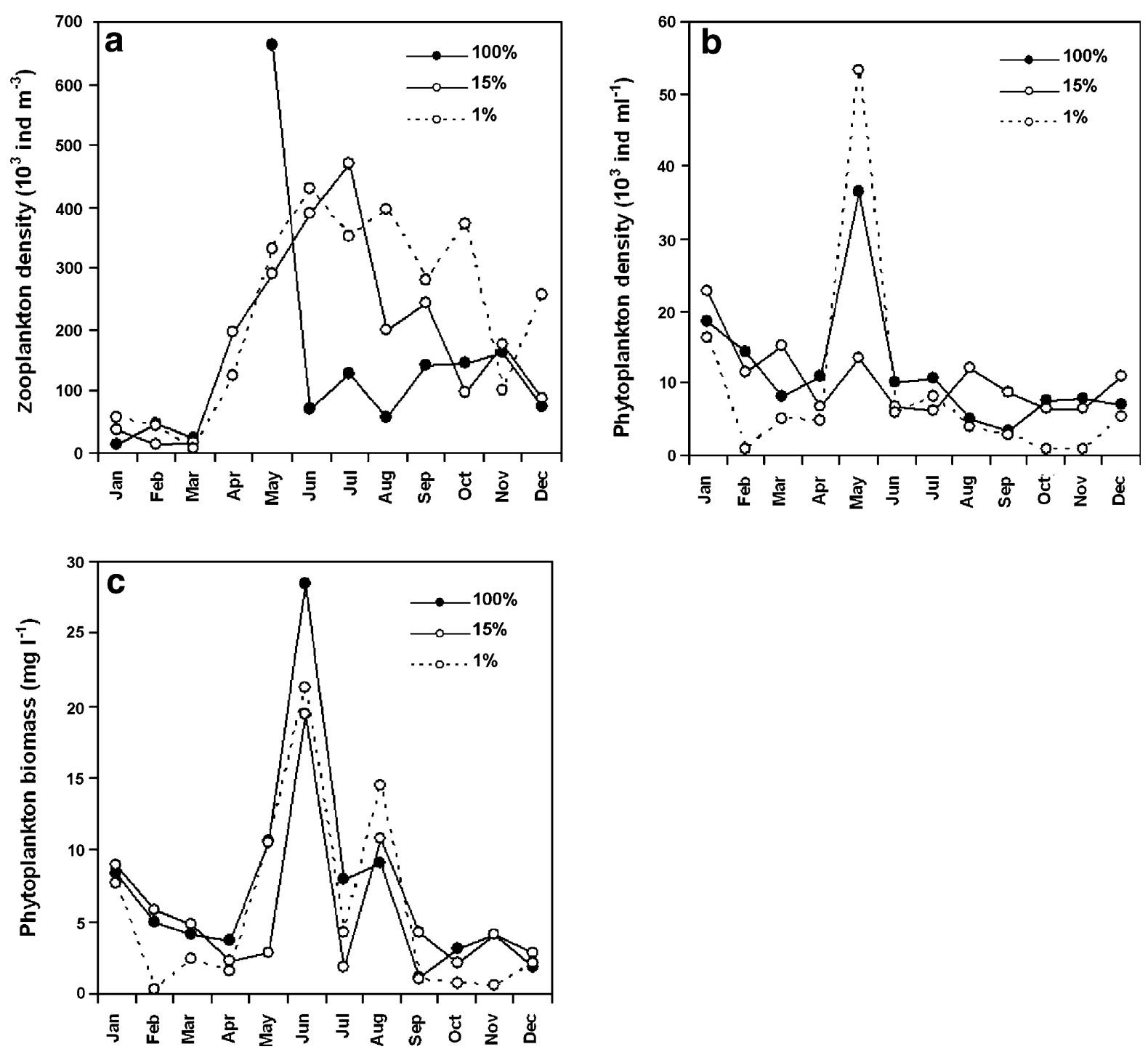

Fig. 2 Monthly changes of (a) total density of zooplankton (ind $\mathrm{m}^{-3}$ ), (b) total density of phytoplankton (ind $\mathrm{ml}^{-1}$ ), and (c) total biomass of phytoplankton $\left(\mathrm{mg} \mathrm{l}^{-1}\right)$ from samples at $100 \%, 15 \%$ and $1 \%$ of incident light of Dom Helvécio Lake, South-East Brazil, in 2002

Staurodesmus and, moreover, Sphaerozosma sp. and Spondylosium sp., which occur in Dom Helvécio Lake largely as unicells as observed not only in Lugol-fixed samples but also in living ones). Other nonmotile green algae (especially chlorococcaleans) may also contribute, occasionally. Assemblage $\mathrm{N}_{\mathrm{A}}$ occurs in clear epilimnia of atelomictic lakes where daily mixing prevents species from sinking ultimately to the hypolimnion. More precisely, short doubling times of species (0.881.32 days was estimated in Barbosa \& Padisák, 2002) together with diurnal resuspension may counterbalance sedimentary (and grazing) losses. Assemblage $\mathrm{N}_{\mathrm{A}}$ is tolerant to nutrient deficiency and mild light and is sensitive to deep mixing and low light. It is also sensitive to grazing because species have small cell sizes. Indication of grazing sensitivity may be that at onset of stratification (Oct-Dec) small, simple forms of desmids (Cosmarium spp.; Staurodesmus incus) were dominant and were gradually replaced by more complex (and, consequently, more grazing resistant) forms like Staurastrum spp. This pattern is similar to the one described in the PEG model (Sommer et al., 1986) where selection of increasingly grazing resistant forms is observable during stratified periods. 
Fig. 3 Changes in (a) mean relative contribution (\%) to total density of major taxonomic groups of zooplankton and (b) mean relative contribution (\%) to total biomass of major groups of phytoplankton, from samples at $100 \%, 15 \%$ and $1 \%$ of incident light of Dom Helvécio Lake, SouthEast Brazil, in 2002
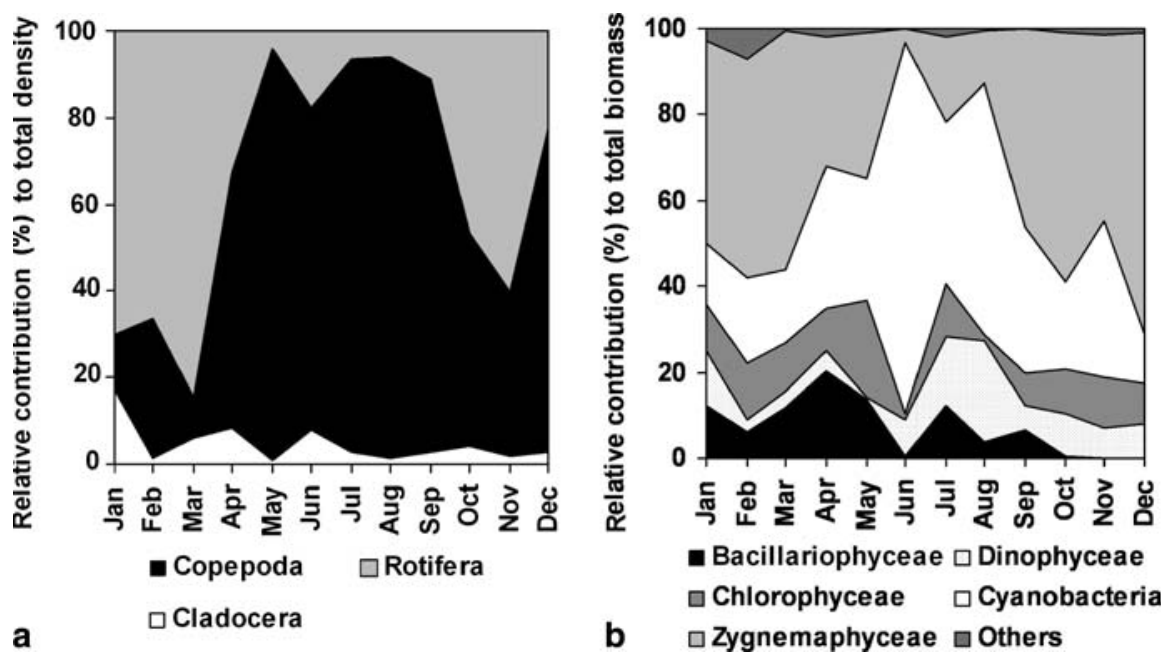

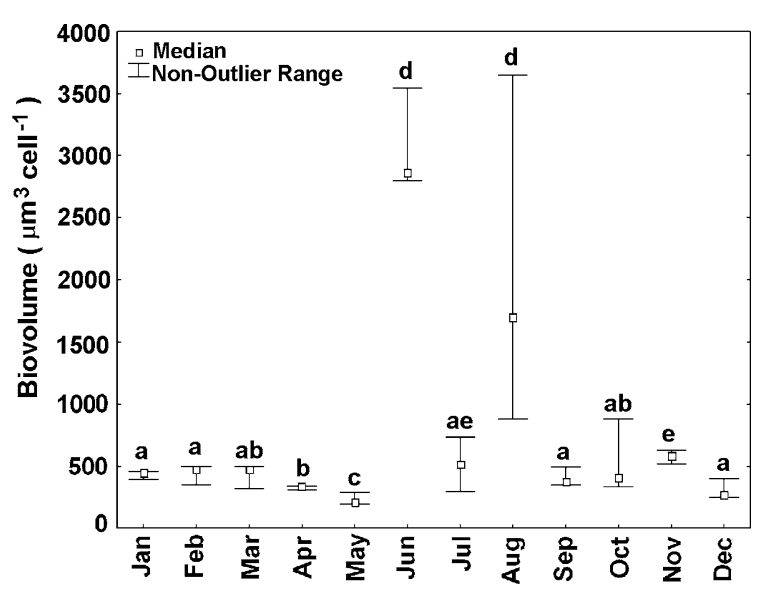

Fig. 4 Monthly changes of median values of phytoplankton cell size $\left(\mu \mathrm{m}^{3}\right.$ cell $\left.^{-1}\right)$ from samples at $100 \%, 15 \%$ and $1 \%$ of incident light of Dom Helvécio Lake, of Dom Helvécio Lake, South-East Brazil, in 2002 (distinct letters indicate significant statistical differences)

Differences in nutrient uptake efficiency of different desmids may also play role in replacements at speciesspecific level (Healey \& Hendzel, 1988). Finally, this key role of atelomixis on explaining desmids presence in other tropical systems has also been shown for Lake Carioca and for other lakes in the middle Rio Doce region, South-East Brazil (Barbosa \& Padisák, 2002), and for Lake Zirahuén, in Central Mexico (Tavera \& Martínez-Almeida, 2005).

Another feature of phytoplankton in Dom Helvécio Lake is presence of S2 and R assemblages that may comprise similar or even the same species of filamentous cyanobacteria (Lyngbya sp. that carries features of Limnothrix sp.—see morphological description in Reynolds (1997b); Planktolyngbya sp.; Spirulina sp.; and, in other years, Cylindrospermopsis raciborskii (see Padisák et al., 2003a), a $\mathrm{S}_{\mathrm{N}} / \mathrm{R}$ species, too). These species are shade tolerant and are dispersed in whole water column during isothermal periods, in Apr-Sep, therefore, they are typical representatives of $\mathrm{S} 2$ assemblage. When thermocline starts to develop, these filamentous cyanobacteria form a dense metalimnetic layer where they are persistent as deep chlorophyll maximum (DCM) until next event of full mixing, therefore, they fulfill description of $\mathrm{R}$ assemblage. Basic ground of qualifying a species to $\mathrm{S} 2$ or $\mathrm{R}$ assemblage is absence or presence of spatial segregation from assemblages in mixed layers.

Seasonal succession of phytoplankton assemblages observed in Dom Helvécio Lake, in 2002, can be best approximated by the sequence of codons: $\mathrm{N}_{\mathrm{A}}-\mathrm{F}(-\mathrm{R}) \rightarrow \mathrm{A}-\mathrm{S} 2-X 1-\mathrm{L}_{\mathrm{O}} \rightarrow \mathrm{N}_{\mathrm{A}}-\mathrm{F}(-\mathrm{R})$, which represents species that frequently coexisted and increased or decreased in biomass simultaneously. This dynamics matched with environmental changes and periods identified, generally characterized by onset of thermal stratification and abruptly terminated by onset of mixing (Reynolds, 1988).

In summary, and according to "rules of assembly" agreed during IAP Workshop in The UK (1998; Reynolds et al., 2000), environmental changes act selecting certain algal traits or attributes (Reynolds, 2000) and making use of assemblages of phytoplankton is an appropriate tool for monitoring ecological 
Table 3 Dominant phytoplankton species (\%, contribution to total biomass) and their assemblages (As.) in depths corresponding to $100 \%, 15 \%$, and $1 \%$ of incident light of Dom Helvécio Lake, South-East Brazil, in 2002

\begin{tabular}{|c|c|c|c|c|c|c|}
\hline \multirow[t]{2}{*}{ Month } & \multicolumn{2}{|c|}{$100 \%$ light } & \multicolumn{2}{|c|}{$15 \%$ light } & \multicolumn{2}{|c|}{$1 \%$ light } \\
\hline & As. & Species & As. & Species & As. & Species \\
\hline \multirow[t]{2}{*}{ Jan } & $\mathrm{N}_{\mathrm{A}}$ & S. smithii $(35 \%)$ & $\mathrm{R}$ & Lyngbya sp. (32\%) & A & U. longiseta $(34 \%)$ \\
\hline & $\mathrm{F}$ & B. braunii $(20 \%)$ & $\mathrm{N}_{\mathrm{A}}$ & S. smithii $(28 \%)$ & $\mathrm{N}_{\mathrm{A}}$ & S. smithii $(36 \%)$ \\
\hline \multirow[t]{2}{*}{ Feb } & $\mathrm{N}_{\mathrm{A}}$ & S. smithii $(38 \%)$ & $\mathrm{N}_{\mathrm{A}}$ & S. smithii $(25 \%)$ & $\mathrm{N}_{\mathrm{A}}$ & S. smithii $(33 \%)$ \\
\hline & $\mathrm{N}_{\mathrm{A}}$ & S. incus $(25 \%)$ & $\mathrm{R}$ & Lyngbya sp. (21\%) & $\mathrm{F}$ & B. braunii $(32 \%)$ \\
\hline \multirow[t]{2}{*}{ Mar } & $\mathrm{N}_{\mathrm{A}}$ & S. smithii $(42 \%)$ & $\mathrm{N}_{\mathrm{A}}$ & S. incus $(59 \%)$ & $\mathrm{N}_{\mathrm{A}}$ & S. smithii $(32 \%)$ \\
\hline & $\mathrm{R}$ & Lyngbya sp. (20\%) & $\mathrm{N}_{\mathrm{A}}$ & S. smithii $(21 \%)$ & $\mathrm{F}$ & B. braunii $(16 \%)$ \\
\hline \multirow[t]{2}{*}{ Apr } & A & U. longiseta $(21 \%)$ & A & U. longiseta $(35 \%)$ & $\mathrm{R}$ & Spirulina sp. (62\%) \\
\hline & $\mathrm{N}_{\mathrm{A}}$ & S. incus $(18 \%)$ & $\mathrm{X} 1$ & Chlorella sp. (15\%) & $\mathrm{N}_{\mathrm{A}}$ & S. smithii $(10 \%)$ \\
\hline \multirow[t]{2}{*}{ May } & $\mathrm{S} 2$ & Lyngbya sp. (24\%) & $\mathrm{X} 1$ & Chlorella sp. (22\%) & $\mathrm{X} 1$ & Chlorella sp. (28\%) \\
\hline & $\mathrm{X} 1$ & Chlorella sp. (17\%) & A & U. longiseta $(19 \%)$ & $\mathrm{S} 2$ & Planktolyngbya sp. (19\%) \\
\hline \multirow[t]{2}{*}{ June } & $\mathrm{S} 2$ & Lyngbya sp. (71\%) & $\mathrm{S} 2$ & Lyngbya sp. (88\%) & $\mathrm{S} 2$ & Lyngbya sp. (73\%) \\
\hline & $\mathrm{L}_{\mathrm{O}}$ & P. inconspicuum (18\%) & $\mathrm{S} 2$ & Planktolyngbya sp. (3\%) & $\mathrm{S} 2$ & Planktolyngbya sp. (13\%) \\
\hline \multirow[t]{2}{*}{ July } & $\mathrm{S} 2$ & Lyngbya sp. (36\%) & A & U. longiseta $(17 \%)$ & $\mathrm{S} 2$ & Lyngbya sp. (38\%) \\
\hline & $\mathrm{L}_{\mathrm{O}}$ & P. inconspicuum (25\%) & $\mathrm{X} 1$ & Chlorella sp. (15\%) & A & U. longiseta $(13 \%)$ \\
\hline \multirow[t]{2}{*}{ Aug } & $\mathrm{N}_{\mathrm{A}}$ & S. panduriforme (17\%) & $\mathrm{S} 2$ & Lyngbya sp. (16\%) & $\mathrm{S} 2$ & Lyngbya sp. (59\%) \\
\hline & $\mathrm{S} 2$ & Lyngbya sp. (16\%) & $\mathrm{L}_{\mathrm{O}}$ & P. inconspicuum (15\%) & $\mathrm{F}$ & B. braunii $(10 \%)$ \\
\hline \multirow[t]{2}{*}{ Sep } & $\mathrm{S} 2$ & Planktolyngbya sp. (21\%) & $\mathrm{S} 2$ & Lyngbya sp. (37\%) & $\mathrm{S} 2$ & Planktolyngbya sp. (22\%) \\
\hline & $\mathrm{N}_{\mathrm{A}}$ & S. smithii $(15 \%)$ & $\mathrm{S} 2$ & Planktolyngbya sp. (10\%) & $\mathrm{N}_{\mathrm{A}}$ & C. contractum (11\%) \\
\hline \multirow[t]{2}{*}{ Oct } & $\mathrm{N}_{\mathrm{A}}$ & C. contractum $(26 \%)$ & $\mathrm{N}_{\mathrm{A}}$ & S. incus $(33 \%)$ & $\mathrm{R}$ & Lyngbya sp. (44\%) \\
\hline & $\mathrm{N}_{\mathrm{A}}$ & S. incus $(26 \%)$ & $\mathrm{N}_{\mathrm{A}}$ & C. contractum $(30 \%)$ & $\mathrm{F}$ & B. braunii $(18 \%)$ \\
\hline \multirow[t]{2}{*}{ Nov } & $\mathrm{N}_{\mathrm{A}}$ & C. contractum $(40 \%)$ & $\mathrm{R}$ & Lyngbya sp. (41\%) & $\mathrm{R}$ & Lyngbya sp. (29\%) \\
\hline & $\mathrm{F}$ & B. braunii $(12 \%)$ & $\mathrm{N}_{\mathrm{A}}$ & C. contractum (29\%) & $\mathrm{N}_{\mathrm{A}}$ & C. contractum (14\%) \\
\hline \multirow[t]{2}{*}{ Dec } & $\mathrm{N}_{\mathrm{A}}$ & C. contractum $(22 \%)$ & $\mathrm{N}_{\mathrm{A}}$ & C. contractum $(32 \%)$ & $\mathrm{N}_{\mathrm{A}}$ & C. contractum $(45 \%)$ \\
\hline & $\mathrm{N}_{\mathrm{A}}$ & S. smithii $(20 \%)$ & $\mathrm{X} 1$ & Chlorella sp. (16\%) & $\mathrm{L}_{\mathrm{O}}$ & P. inconspicuum (11\%) \\
\hline
\end{tabular}

Labels according to: Padisák \& Reynolds (1998), Huszar et al. (2000), Reynolds (2000), Reynolds et al. (2002), and Kruk et al. (2002). See description of assemblage $\mathrm{N}_{\mathrm{A}}$ in discussion. Abbreviations of genus names: B., Botryococcus; C., Cosmarium; P., Peridinium; S., Staurastrum/Staurodesmus/Spondylosium; U., Urosolenia

status of lakes (Padisák et al., 2006), including tropical ones. In this sense, main representatives of $\mathrm{N}_{\mathrm{A}}$ (Staurastrum smithii, Cosmarium spp., Staurodesmus incus) and $\mathrm{F}$ (Botryococcus braunii) assemblages were selected because they possess advantageous adaptations to grow under stratification conditions either because they are favored by oligotrophy (Huszar et al., 1998) combined with partial atelomixis (Barbosa \& Padisák, 2002) as the roughly isodiametric desmids, or due to anti-sinking strategies, as verified for large-sized green algae (NaselliFlores \& Barone, 1998).

Dominant species during the dry period (Apr-Sep) are medium-large centric diatoms (Urosolenia longiseta), filamentous blue-greens (Lyngbya sp. and
Planktolyngbya sp.), dinoflagellates (Peridinium inconspicuum and Gymnodinium sp.), and small spherical green algae (Chlorella $\mathrm{sp}$.) that are associated to assemblages $\mathrm{A}, \mathrm{S} 2, \mathrm{~L}_{\mathrm{O}}$, and X1; all tolerating mixing and light deficiency (Reynolds, 1993; Naselli-Flores, 2000; Nixdorf et al., 2003) and having (except for Chlorella sp.) a remarkable capacity for buoyancy regulation, for chromatic acclimation, for grazing resistance (Dokulil \& Teubner, 2003), or for being opportunistic (Melo \& Huszar, 2000).

Considering data as a whole, we could not only identify bottom-up controls of phytoplankton distribution but also top-down ones. On the one hand, density of rotifers (smaller organisms, generalists) was related to stratification periods when nutrient 


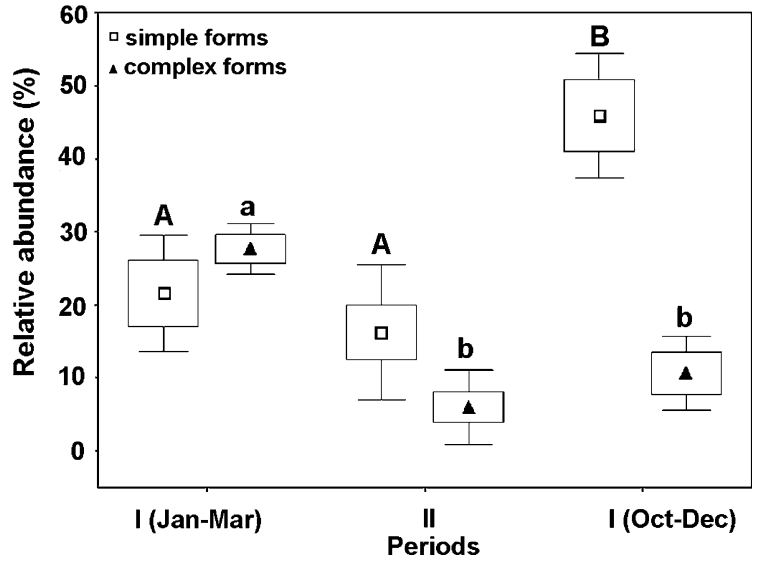

Fig. 5 Relative contribution (\%) to total biomass of simple and complex shapes of desmids from samples at $100 \%, 15 \%$ and $1 \%$ of incident light in Dom Helvécio Lake, South-East Brazil, within two recognized periods: I (rainy months) and II (dry months), in 2002 (distinct letters indicate significant statistical differences)

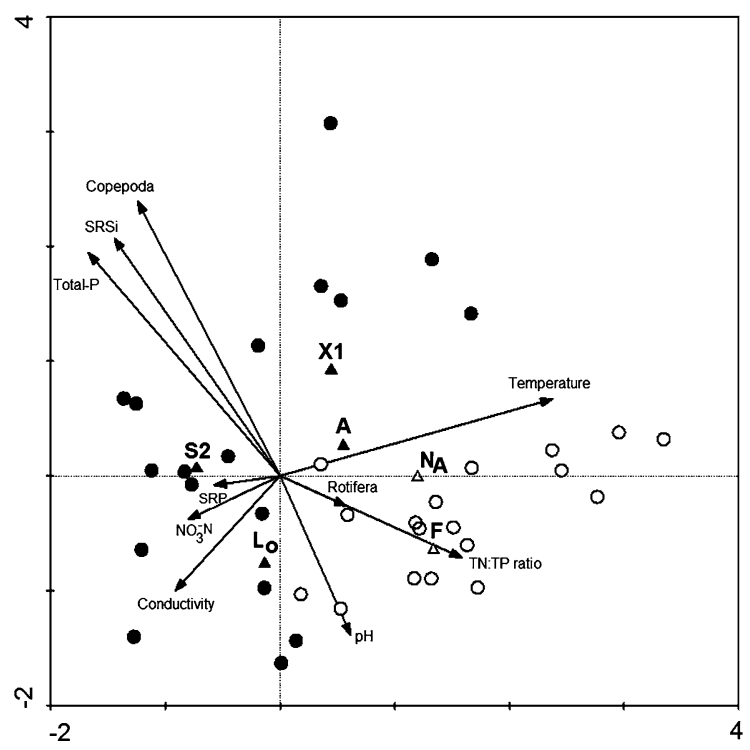

Fig. 6 CCA ordination diagram considering samples within the euphotic zone of two recognized periods in 2002 of Dom Helvécio Lake, South-East Brazil, with density of copepods, density of rotifers, and abiotic variables as vectors, and the most representative phytoplankton assemblages $\left(\mathrm{N}_{\mathrm{A}}, \mathrm{F}, \mathrm{A}, \mathrm{X} 1\right.$, $\mathrm{L}_{\mathrm{o}}, \mathrm{S} 2$ ) on bi-dimensional space of first and second axes. White dots represent samples from the first period (six rainy months) and black dots represent samples from the second period (six dry months)

availability decreased and bottom-up control prevailed (Reynolds, 1988; Buzzi, 2002) favoring species that prefer oligotrophy with good light
Table 4 Results of CCA performed for Dom Helvécio Lake, South-East Brazil, using abiotic and biological variables considering samples within the euphotic zone of two recognized periods (six rainy and six dry months, in 2002)

\begin{tabular}{lll}
\hline Results & Axis 1 & Axis 2 \\
\hline Eigenvalues $(\lambda)$ & 0.409 & 0.111 \\
Species-environment correlations & 0.910 & 0.800 \\
$\begin{array}{l}\text { Cumulative percentage variance } \\
\quad \text { of species-environment relation }(\%)\end{array}$ & 64.1 & 81.6 \\
$F$-ratio & 16.1 & 5.9 \\
$P$-value & $<0.001$ & $<0.05$ \\
\hline
\end{tabular}

Table 5 Canonical correlation coefficients of environment and biotic vectors with ordination axes 1 and 2 for CCA performed for Dom Helvécio Lake, South-East Brazil, considering samples within the euphotic zone of two recognized periods (six rainy and six dry months, in 2002)

\begin{tabular}{lcc}
\hline Variables & \multicolumn{2}{c}{ Canonical correlation coefficient } \\
\cline { 2 - 3 } & Axis 1 & Axis 2 \\
\hline Temperature & 0.7988 & 0.1614 \\
Density of Rotifera & 0.1937 & -0.0633 \\
TN:TP ratio & 0.5332 & -0.1721 \\
pH & 0.2069 & -0.3354 \\
Conductivity & -0.3081 & -0.2414 \\
N-NO & -0.2698 & -0.0911 \\
SRP & -0.1930 & -0.0196 \\
Total-P & -0.5628 & 0.4692 \\
SRSi & -0.4874 & 0.5003 \\
Density of Copepoda & -0.4180 & 0.5778 \\
\hline
\end{tabular}

conditions and increased stability of stratification. On the other hand, copepods, mainly represented by Thermocyclops minutus (larger organisms, omnivorous), were associated with mixing period and with less available light, suggesting that top-down controls also influenced phytoplankton composition. Results indicated that compositional phytoplankton variations might have responded to enrichment in nutrients, light availability, and zooplankton pressure.

In conclusion, replacement of phytoplankton assemblages in Dom Helvécio Lake depends on physical factors that determine changes in mixing and light conditions followed by nutrient enrichment, especially phosphorus, and by zooplankton consumption, that might result in a cyanobacteria state maintenance. Results also corroborate functional assemblages approach as a valuable tool (Kruk et al., 
2002; Padisák et al., 2006; Hajnal \& Padisák, 2008) also when evaluating environmental changes of tropical water bodies; therefore, we suggest that it can be further used to assess quality of waters of the middle Rio Doce Lake District.

Acknowledgments We thank the Limnology Group at the Institute of Biological Sciences of the Federal University of Minas Gerais (ICB-UFMG) for helpful discussions, laboratory, and field work assistance. We also wish to thank two anonymous reviewers for their critical reading and valuable comments on the manuscript. This study was conducted within the Graduate Program in Ecology, Conservation and Wildlife Management of the UFMG, supported by the US Fish and Wildlife Service. We are grateful to CAPES (Ministry of Education, Brazil) for the M.Sc. scholarship and CNPq for the financial support of the Brazilian-LTER Program (Process No 520031/98-9).

Open Access This article is distributed under the terms of the Creative Commons Attribution Noncommercial License which permits any noncommercial use, distribution, and reproduction in any medium, provided the original author(s) and source are credited.

\section{References}

Barbosa, F. A. R., 1994. Why a Brazilian program on conservation and management of aquatic ecosystems? Acta Limnologica Brasiliensia 5: 13-18.

Barbosa, F. A. R., 1997. The importance of diurnal cycles for the conservation and management of tropical waters: examples from the Rio Doce Valley lakes system. In Tundisi, J. G. \& Y. Saijo (eds), Limnological Studies in the Rio Doce Valley Lakes. Brazilian Academy of Sciences, São Carlos: 449-456.

Barbosa, F. A. R. \& J. Padisák, 2002. The forgotten lake stratification pattern: atelomixis, and its ecological importance. Verhandlungen internationale Vereinigung für theoretische und angewandte Limnologie 28: 1385-1395.

Barbosa, F. A. R., F. R. Scarano, M. G. Sabará \& F. A. Esteves, 2004. Brazilian LTER: ecosystem and biodiversity information in support of decision-making. Environmental Monitoring and Assessment 90: 121-133.

Barros, C. F. A., M. B. G. Souza \& F. A. R. Barbosa, 2006. Seasonal forces driving phytoplankton size structure in a tropical deep lake (Dom Helvécio Lake, South-East Brazil). Acta Limnologica Brasiliensia 18: 55-66.

Becker, V., L. S. Cardoso \& V. L. M. Huszar, 2008. Diel variation of phytoplankton functional groups in a subtropical reservoir in southern Brazil during an autumnal stratification period. Aquatic Ecology doi:10.1007/ s10452-008-9164-0.

Borics, G., I. Grigorszky, J. Padisák, F. A. R. Barbosa \& Z. Z. Doma, 2005. Dinoflagellates from tropical Brazilian lakes with description of Peridinium brasiliense sp. nov. Algological Studies 118: 47-61.
Bottrell, H. H., A. Duncan, Z. M. Gliwicz, E. Grygierek, A. Herzig, A. Hillbricht-Ilkowska, H. Kurasaua, P. Larsson, \& T. Weglenska, 1976. A review of some problems in zooplankton production studies. Norwegian Journal of Zoology 24: 419-456.

Bouvy, M., S. M. Nascimento, R. J. R. Molica, A. Ferreira, V. Huszar \& S. M. F. O. Azevedo, 2003. Limnological features in Tapacurá reservoir (northeast Brazil) during a severe drought. Hydrobiologia 493: 115-130.

Bouvy, M., B. Ngansoumana, S. Ka, S. Sane, M. Pagano \& R. Arfi, 2006. Phytoplankton community structure and species assemblage succession in a shallow tropical lake (Lake Guiers, Senegal). Aquatic Microbial Ecology 45: 147-161.

Buzzi, F., 2002. Phytoplankton assemblages in two sub-basins of Lake Como. Journal of Limnology 61: 117-128.

Cole, G. A., 1983. Textbook of Limnology. The C.V. Mosby Company, St. Louis.

de Meis, M. R. M. \& J. G. Tundisi, 1997. Geomorphological and Limnological process as a basis for lake typology. The middle Rio Doce lake system. In Tundisi J. G. \& Y. Saijo (eds), Limnological Studies in the Rio Doce Valley Lakes. Brazilian Academy of Sciences, São Carlos: 25-50.

Dokulil, M. T. \& K. Teubner, 2003. Steady state phytoplankton assemblages during thermal stratification in deep alpine lakes. Do they occur? Hydrobiologia 502: 65-72.

Edler, L., 1979. Recommendation for Marine Biological Studies in the Baltic Sea: Phytoplankton and Chlorophyll. Unesco, Paris.

Fabbro, L. D. \& L. J. Duivenvoorden, 1996. Profile of a bloom of the cyanobacterium Cylindrospermopsis raciborskii (Woloszynska) Seenaya and Subba Raju in the Fitzroy River in Tropical Central Queensland. Marine \& Freshwater Research 47: 685-694.

Figueredo, C. C. \& A. Giani, 2001. Seasonal variation in the diversity and species richness of phytoplankton in a tropical eutrophic reservoir. Hydrobiologia 445: 165-174.

Forte-Pontes, M., 1980. Produção primária, fitoplâncton e fatores ambientais no Lago Dom Helvécio, Parque Florestal do rio Doce-MG. M.Sc. Thesis, Federal University of São Carlos, São Carlos.

Golterman, H. L., R. S. Clymo \& M. A. M. Ohnstad, 1978. Methods for Physical and Chemical Analysis of Freshwaters. Blackwell Scientific Publications, Oxford.

Gosselain, V. \& P. B. Hamilton, 2000. ALGAMICA: revisions to a key-based computerized counting program for free living, attached and benthic algae. Hydrobiologia 438: 139-142.

Gunkel, G. \& J. Casallas, 2002. Limnology of an equatorial high mountain lake-Lago San Pablo, Ecuador: the significance of deep diurnal mixing for lake productivity. Limnologica 32: 33-43.

Hajnal, É. \& J. Padisák, 2008. Analysis of long-term ecological status of Lake Balaton based on the ALMOBAL phytoplankton database. Hydrobiologia 599: 227-237.

Hambright, K. D., M. Gophen \& S. Serruya, 1994. Influence of long-term climatic changes on the stratification of a subtropical warm monomictic lake. Limnology \& Oceanography 39: 1233-1242.

Healey, F. P. \& L. L. Hendzel, 1988. Competition for phosphorus between desmids. Journal of Phycology 24: 287-292. 
Henry, R. \& F. A. R. Barbosa, 1989. Thermal structure, heat content and stability of two lakes in the National Rio Doce Valley Lakes (Minas Gerais, Brazil). Hydrobiologia 181: 189-199.

Henry, R., J. G. Tundisi, M. C. Calijuri, \& M. S. R. Ibañez, 1997. Geomorphological and limnological process as a basis for lake typology. The middle Rio Doce lake system. In Tundisi J. G. \& Y. Saijo (eds), Limnological Studies in the Rio Doce Valley Lakes. Brazilian Academy of Sciences, São Carlos: 69-77.

Huszar, V. L. M. \& N. Caraco, 1998. The relationship between phytoplankton composition and physical-chemical variables: a comparison of taxonomic and morphologicalfunctional descriptors in six temperate lakes. Freshwater Biology 40: 679-696.

Huszar, V. L. M., L. H. S. Silva, P. Domingos, M. Marinho \& S. Melo, 1998. Phytoplankton species composition is more sensitive than OECD criteria to the trophic status of three Brazilian tropical lakes. Hydrobiologia 369/370: 59-71.

Huszar, V. L. M., L. H. S. Silva, M. Marinho, P. Domingos \& C. L. Sant'Anna, 2000. Cyanoprokaryote assemblages in eight productive tropical Brazilian waters. Hydrobiologia 424: 67-77.

Hutchinson, G. E., 1957. A Treatise on Limnology, Vol. 1. John Wiley \& Sons, New York.

Jensen, P., E. Jeppensen, K. Olrik \& P. Kristensen, 1994. Impact of nutrients and physical factors on the shift from cyanobacterial to chlorophyte dominance in Danish lakes. Canadian Journal of Fisheries and Aquatic Sciences 51: 1692-1699.

Koroleff, F., 1976. Determination of ammonia. In Grasshoff, K. (ed.), Methods of Seawater Analysis. Verlag Chemie, Weinheim: 126-133.

Kruk, C., N. Mazzeo, G. Lacerot \& C. S. Reynolds, 2002. Classification schemes for phytoplankton: a local validation of a functional approach to the analysis of species temporal replacement. Journal of Plankton Research 24: 901-912.

Lewis, W. M. Jr., 1978. Dynamics and succession of the phytoplankton in a tropical lake: Lake Lanao, Philippines. Journal of Ecology 66: 849-880.

Lopes, M. R. M., C. E. M. Bicudo \& M. C. Ferragut, 2005. Short term spatial and temporal variation of phytoplankton in a shallow tropical oligotrophic reservoir, southeast Brazil. Hydrobiologia 542: 235-247.

Lund, J. W. G., C. Kipling \& E. D. LeCren, 1958. The inverted microscope method of estimating algal number and the statistical basis of estimation by counting. Hydrobiologia 11: $143-170$.

Mackereth, F. J. H., J. Heron \& J. F. Talling, 1978. Water Analysis. Scientific Publication No 36. Freshwater Biological Association, Ambleside.

Melack, J. M., 1979. Temporal variability of phytoplankton in tropical lakes. Oecologia (Berlin) 44: 1-7.

Melo, S. \& V. L. M. Huszar, 2000. Phytoplankton in an Amazonian flood-plain lake (Lago Batata, Brasil): diel variation and species strategies. Journal of Plankton Research 22: 63-76.

Myers, N., R. A. Mittermeier, C. G. Mittermeier, G. A. B. Fonseca \& J. Kent, 2000. Biodiversity hotspots for conservation priorities. Nature 403: 853-858.
Naselli-Flores, L., 2000. Phytoplankton assemblages in twentyone Sicilian reservoirs: relationships between species composition and environmental factors. Hydrobiologia 424: 1-11.

Naselli-Flores, L. \& R. Barone, 1998. Phytoplankton dynamics in two reservoirs with different trophic state (Lake Rosamarina and Lake Arancio, Sicily, Italy). Hydrobiologia 369/370: 163-178.

Naselli-Flores, L., J. Padisák, \& M. Albay, 2007. Shape and size in phytoplankton ecology: do they matter? Hydrobiologia 578: 157-161.

Nimer, N., 1989. Climatologia do Brasil, 2nd edn. Instituto Brasileiro de Geografia e Estatística, Rio de Janeiro.

Nixdorf, B., U. Mischke \& J. Rücker, 2003. Phytoplankton assemblages and steady state in deep and shallow eutrophic lakes - an approach to differentiate the habitat properties of Oscillatoriales. Hydrobiologia 502: 111-121.

Padisák, J., F. A. R. Barbosa, R. Koschel \& I. Krienitz, 2003a. Deep layer cyanoprokaryota maxima are constitutional features of lakes: examples from temperate and tropical regions. Archiv für Hydrobiologie-Special Issues Advances in Limnology 58: 175-199.

Padisák, J., G. Borics, G. Fehér, I. Grigorszky, I. Oldal, A. Schmidt \& Z. Zámbóné-Doma, 2003b. Dominant species and frequency of equilibrium phases in late summer phytoplankton assemblages in Hungarian small shallow lakes. Hydrobiologia 502: 157-168.

Padisák, J., I. Grigorszky, G. Borics \& E. Soróczki-Pintér, 2006. Use of phytoplankton assemblages for monitoring ecological status of lakes within the water framework directives: the assemblage index. Hydrobiologia 553: 1-14.

Padisák, J. \& C. S. Reynolds, 1998. Selection of phytoplankton associations in Lake Balaton, Hungary, in response to eutrophication and restoration measures, with special reference to the cyanoprokaryotes. Hydrobiologia 384: 41-53.

Reynolds, C. S., 1984. The Ecology of Freshwater Phytoplankton. Cambridge University Press, Cambridge.

Reynolds, C. S., 1988. The concept of ecological succession applied to seasonal periodicity of freshwater phytoplankton. Verhandlungen internationale Vereinigung für theoretische und angewandte Limnologie 23: 683-691.

Reynolds, C. S., 1993. Scales of disturbance and their role in plankton ecology. Hydrobiologia 249: 157-171.

Reynolds, C. S., 1997a. Vegetation Processes in the Pelagic. A Model for Ecosystem Theory. The International Ecology Institute, Oldendorf.

Reynolds, C. S., 1997b. On the vertical distribution of phytoplankton in the middle Rio Doce valley lakes. In Tundisi J. G. \& Y. Saijo (eds), Limnological Studies in the Rio Doce Valley Lakes. Brazilian Academy of Sciences, São Carlos: 227-241.

Reynolds, C. S., 2000. Phytoplankton designer-or how to predict compositional responses to trophic change. Hydrobiologia 424: 123-132.

Reynolds, C. S., M. T. Dokulil \& J. Padisák, 2000. Understanding the assembly of phytoplankton in relation to the trophic spectrum: where are we now? Hydrobiologia 424: 147-152.

Reynolds, C. S., V. L. M. Huszar, C. Kruk, L. Naselli-Flores \& S. Melo, 2002. Towards a functional classification of the 
freshwater phytoplankton. Journal of Plankton Research 24: 417-428.

Salmaso, N. \& J. Padisák, 2007. Morpho-functional groups and phytoplankton development in two deep lakes (Lake Garda, Italy and Lake Stechlin, Germany). Hydrobiologia 578: 97-112.

Sommer, U., Z. M. Gliwicz, W. Lampert \& A. Duncan, 1986. The PEG-model of seasonal succession of planktonic events in freshwaters. Archiv für Hydrobiologie 106: 433-471.

Tavera, R. \& V. Martínez-Almeida, 2005. Atelomixis as a possible driving force in the phytoplankton composition of Zirahuén, a warm-monomictic tropical lake. Hydrobiologia 533: 199-208.
Ter Braak, C. J. F. \& P. Šmilauer, 1998. CANOCO Reference Manual and User's Guide to CANOCO for Windows. Centre for Biometry, Wageningen.

Townsend, S., 2006. Hydraulic phases, persistent stratification, and phytoplankton in a tropical floodplain lake (Mary River, Northern Australia). Hydrobiologia 556: 163-179. Tundisi, J. G., 1997. Climate. In Tundisi J. G. \& Y. Saijo (eds), Limnological Studies in the Rio Doce Valley Lakes. Brazilian Academy of Sciences, São Carlos: 7-11.

Utermöhl, H., 1958. Zur Vervollkomnung der quantitativen Phytoplankton-Methodik. Verhandlungen internationale Vereinigung für theoretische und angewandte Limnologie 9: $1-38$. 